\title{
Hoover, the Red Cross and Food for the Hungry*
}

C. Roger Lambert

FOOD FOR HUNGRY AMERICANS BECAME ONE OF THE MOST controversial issues of the Depression years of the Herbert Hoover presidency. As reports of malnutrition and starvation became more insistent, humanitarians began to demand federal food programs. Hoover's philosophy of local responsibility and self-help, and his belief that no one actually was starving, countered that demand. Since the president opposed federal involvement in direct relief to individuals, he called upon the Red Cross to perform what many considered ought to be government functions. By 1932 the food issue had had major effects on both the Red Cross and Hoover. The charity organization had assumed new responsibilities for general Depression relief, and the president had misused opportunities and thereby forfeited his role as the greatest international humanitarian.

Hoover's position on relief was based on his view of the Depression, and was reinforced by his idealistic philosophy. He argued that individual dependence upon the central government would sap the moral and spiritual fiber of the nation and would inevitably lead to decay and destruction. He opposed "any direct or indirect dole. . . . For our people are providing against distress from unemployment in true American fashion by a

*A version of this paper was read at the Northern Great Plains History Conference in October, 1973, Sioux Falls, South Dakota. Grants from the Research Committee, Arkansas State University, and The Eleanor Roosevelt Institute permitted research on this topic. 
magnificent response to public appeal and by action of the local government ..." ${ }^{1}$ The local charity organizations Hoover contended, must assume the responsibility for relief, aided and supported by local government.

The Red Cross policies and attitudes were consistent with Hoover's. John Barton Payne, chairman, declared that unemployment relief "is a local problem, pure and simple....." "There is," he insisted, "no possible reason why the Federal government should be called up." Yet the Red Cross was not anxious to get involved in the gradual-creeping natural disasters brought by prolonged drought, and it emphasized that its involvement in feeding hungry Americans or aiding Depression sufferers would drain money and effort from those charity agencies supposed to do that work. ${ }^{2}$ Just as Hoover wanted to disassociate the national government from relief efforts, so did the Red Cross try to disavow responsibility to Depression victims.

The federal role in meeting unemployment problems called for voluntary action by individuals, employers and charity organizations. Hoover pledged, but left partially unfulfilled, a major expansion in public works. As an inspirational act, he established an emergency Committee for Employment, which was followed in August 1931 by "The President's Organization on Unemployment Relief," headed by Walter S. Gifford, president of American Telephone and Telegraph. ${ }^{3}$ Sometime later, in test-

'Joseph Huthmacher and Warren I. Susman, editors, Herbert Hoover and the Crisis of American Capitalism (Cambridge, Mass.: Schenkman Publishing, 1973); Gary H. Koerselman, Herbert Hoover and the Farm Crisis of the Twenties (Unpublished PHD Dissertation, Northern Illinois University, 1971); Albert Romasco, The Poverty of Abundance; Hoover, the Nation, the Depression (New York: Oxford University Press, 1965); Murray N. Rothbard, America's Great Depression (Princeton, N.J.: Van Nostrand, 1963); Jordan Scharz, The Interregum of Despair: Hoover Congress and the Depression (Urbana: University of Illinois Press, 1970); Harold M. Hyman, editor, Herbert Hoover at the Onset of the Great Depression, 1929-1930 (New York: J. D. Lippincott Company, 1975); Joan Hoff Wilson, Herbert Hoover, Forgotten Progressive (Boston: Little, Brown and Company, 1975); Josephine Chapin Brown, Public Relief. 1929-1939 (New York: Henry Holt and Co., 1940).

II Ibid.; Undated Statement by Judge John Barton Payne on the Refusal of the Red Cross to accept a federal grant, File 1-E/113, HPL; DeWitt Smith to James L. Fieser, September 20, 1930, File 1-E/113; The American National Red Cross in the Unemployment Situation, Confidential Memo, February 25, 1932, File 1-E/62, HPL; Foster Rea Dulles, The American Red Cross: A History (New York: Harper and Brothers, 1950), 277, 283-284; New York Times, July 30, 1931.

${ }^{3}$ Harry L. Hopkins, Spending to Save: the Complete Story of Relief (New York: W. W. Norton, 1936), 43. 
imony before a Senate committee, Gifford clearly explained the work of his organization and the attitude of the administration toward relief:

The Central organization in Washington-my organization-was not to do anything other than to encourage the states to do the work; in other words, the responsibility was to be left squarely with the states, counties, and communities. ${ }^{4}$

The phrase "not to do anything" meant that the organization made little effort to determine the number of needy. Nor did it determine how adequately the "states, counties, and communities" were meeting the need. Congressional hearings, the newspapers, and reports by relief representatives and health authorities made it clear that local and voluntary agencies could not meet the relief load. President Hoover, however, remained adamant in his opposition to federal involvement. When pressed, he declared that if federal aid became the "only alternative to starvation" then he would support it. But, he proclaimed, "I have faith in the American people that such a day shall not come," and he never accepted the fact that it had. ${ }^{5}$ Hoover refuted the claims of food shortages:

The evidence of the Public Health Service shows an actual decrease of sickness and infant and general mortality below normal years. No greater proof could be adduced that our people have been protected from hunger and cold and that the sense of social responsibility in the Nation has responded to the need of the unfortunate. ${ }^{6}$

The administration urged donations to voluntary agencies, expected local government to act, and looked for various methods of individual initiative to meet the relief needs. Although charity organizations and some state and local governments made efforts to aid the needy, the results were woefully inadequate. Individual efforts to aid the needy ranged from the heart warming to the absurd. A few people shared their already

4 Ibid., 63.

${ }^{5}$ Arthur M. Schlesinger, The Crisis of the Old Order, 1919-1933 (Boston: Houghton Mifflin Company, 1957), 170; Herbert Hoover, The Memoirs of Herbert Hoover: The Great Depression 1929-1941 (New York: The Macmillan Company, 1952), 56.

${ }^{6}$ Frances Fox Piven and Richard A. Cloward, Regulating the Poor: The Functions of Public Welfare (New York: Random House, 1971), 54; George McLeod to Senator David Reed, January 4, 1932, Hopkins Papers, Franklin D. Roosevelt Library. 


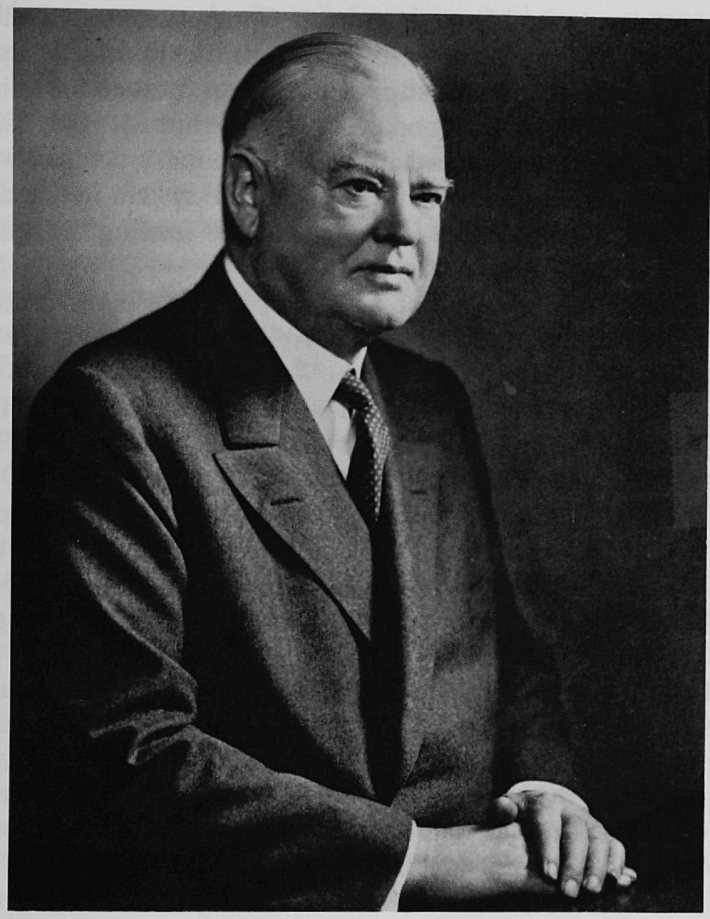

Formal portrait, photographed by Fabian Bachrach, for use on the dust jacket of The Memoirs of Herbert Hoover (Macmillan.)

inadequate food with those less fortunate. School teachers, underpaid and at times unpaid, established lunch programs for their students.

Depression adversities were aggravated by drought in many sections of the nation. In Arkansas hunger and want shifted attention from general unemployment to more specific problems induced by weather. In August 1930, widespread reports of hungry people and farm animals came from Arkansas and 
much of the trans-Mississippi west. Congressmen pushed federal food and feed programs. The administration, after apparently contradicting itself, supported feed assistance for animals but opposed any federal food program. ${ }^{7}$ Arthur M. Hyde, Secretary of Agriculture, warned that feeding hungry people "would constitute a dangerous step toward the dole system in this country." It might thus establish a precedent for feeding the millions of unemployed in the cities. ${ }^{8}$

The issue led to a major fight over relief priorities between Congress and the president. While Arkansas representative Tillman Parks was charging that the "Administration would feed Jackasses, but it wouldn't feed starving babies," the efforts to force either a food program for drought victims or for all hungry Americans continued through the winter of 1930-31.9 Arkansas congressmen first sought to secure a federal appropriation of twenty million for food loans to hungry drought victims. Administration opposition and the desire of urban liberals to extend this to the city unemployed prevented its passage in Congress.

Hoover wanted the Red Cross to provide relief-including food for the hungry-in the drought areas. He felt this was the proper form of relief because it would permit that great spiritual outpouring of the haves to the have-nots. When it was clear that direct food assistance had been blocked, Arkansas Senator Joe T. Robinson led a movement to grant the Red Cross twenty-five million which could be used for both drought and urban relief. The president opposed and John Barton Payne, chairman of the Red Cross, refused the grant because "the welfare of the Red Cross and those it is now helping and will help in the future require that it continue its historic voluntary role and refuse to be drawn into politics." Although the Red Cross had used public funds in earlier crises, this killed the grant movement. ${ }^{10}$

Senator T. H. Caraway of Arkansas charged that Hoover was using the relief organization as "a political screen" to cover his opposition to food assistance and pushed still another fed-

'Roger Lambert, "Hoover and the Red Cross in the Arkansas Drought of 1930," Arkansas Historical Quarterly, 29 (Spring 1970), 7-8.

'Hopkins, Spending to Save, 33.

'Lambert, "Hoover and the Red Cross," 8-16.

${ }^{10}$ Ibid., 15-16. 
eral loan measure. As the relief problem in Arkansas proved far greater than the administration had anticipated, as criticism of the Red Cross appeared, and as political pressures increased, Congress reached a compromise. A twenty million dollar appropriation was added to the earlier feed and seed loan, and it was understood that it could be used for food. Although the money would go to the planters and landlords instead of the hungry croppers and tenants, the measure was quite satisfactory to the Arkansas representatives. The final relief legislation was almost identical to the one which Arkansans had proposed three months earlier. All that Hoover had accomplished in his months of opposition was to build a reputation for being tight, hardhearted and anti-relief. ${ }^{11}$ More important, perhaps, he misused an opportunity for strong, effective leadership in meeting the nation's relief needs. By denying federal responsibility and emphasizing voluntary-that is, Red Cross-action Hoover forfeited the mantle of humanitarian concern to the Democrats.

Unemployment or Depression relief remained a difficult matter for the Red Cross to resolve. Since the the problem originated out of economic failure, the Red Cross policy was to leave to local government and other charity organizations all provisions of assistance for the unemployed. James L. Fieser, vice-chairman of the Red Cross, said "unemployment relief was also definitely outside the Red Cross field," and he considered it a "menace to the future of the Red Cross to become involved in the unemployment question." Red Cross officials argued that such involvement would mean entanglements in politics and deprivation of voluntary fundis for local charity organizations. ${ }^{12}$

Bitter criticism was leveled at the Red Cross in 1932. Although somewhat extreme, the view expressed by John L. Lewis was not unique.

The only thing that apparently inspires the Red Cross to extend assistance is a conflagration, flood, pestilence, and war. It doesn't make any difference to them how many people die of starvation, how many children suffer from malnutrition or how many women are weakened..$^{13}$

"Ibid., 15.

${ }^{12}$ The American National Red Cross in the Unemployment Situation, Confidential Memo, February 25, 1932, File 1-E/62, HPL; Dulles, The American Red Cross, 283-284.

${ }^{13}$ New York Times, January 5, 1932. 
The Red Cross was in the process of broadening its services. In 1931 drought relief and cooperation with other charity organizations to provide unemployment relief would be undertaken with less reluctance than that demonstrated in the Arkansas drought of 1930. In 1932 the Red Cross was almost eager to assume a broader relief responsibility and some officials seemed to assume that the organization would soon take on a broad unemployment relief role.

The question of Federal Farm Board wheat and unemployment relief demonstrated even more clearly the lost chances of the Hoover administration and the increasingly larger role played by the Red Cross. ${ }^{14}$ The Farm Board, created in 1929, sought to maintain farm prosperity by providing for the purchase of vast quantities of wheat and cotton. As it soon became clear that there was little chance of traditional market disposal of the wheat, the idea of using these surplus supplies for relief purposes appeared early in 1930. The public expressed fears that the government might dump the wheat in the ocean or destroy it in some similar way. E. W. Brickert, a "Christian Minister and Farmer" and a Republican of Delaware, warned the president against such a "sinful and foolish" idea and suggested that the wheat be given to the "great army of the unemployed, who can NOT buy wheat, or flour." ${ }^{15}$ This idea, with innumerable variations, appeared again and again during the next two years. The best developed plan for use of government wheat came in the fall of 1930 from J. R. McCleskey, Executive Director of the Economic Conservation Committee of America, and William Gibbs McAdoo. The plan called for a three-man commission which would supervise the distribution of the wheat through the Red Cross and other philanthropic organizations. ${ }^{16}$

McCleskey contacted Hoover and members of the cabinet and urged the administration to adopt the program. He warned

${ }^{14}$ The Federal Farm Board was part of the Hoover solution to the farm problem. Hoover believed that "voluntary cooperation" was the only way to solve the farm price, surplus production problem without destroying the individualism of the farmer. The Farm Board was to encourage and aid cooperatives and, in emergency, create stabilization efforts, including the purchase of low priced surpluses. James L. Fieser to John Barton Payne, May 19, 1932, File 1-E/62, HPL.

${ }^{15}$ E. W. Brickert to Lawrence Ritchey, March 27, 1930, File L-E/160, HPL.

${ }^{10}$ W. G. McAdoo to Joe T. Robinson, November 30, 1930; J. R. McCleskey to Ray Lyman Wilbur, December 8, 1930, File 1-E/161, HPL; J. R. McCleskey to Herbert Hoover, December 5, 1930, File 1-E/161, HPL. 
Hoover that "the desperation born of hunger breeds a mental attitude which cannot be permitted to gain a foothold among so large a mass of our people as are now destitute." He also told Hoover that "public thought is crystalizing in the full expectancy that the president will do something definite and practical and immediate to help feed the people who are hungry now." ${ }^{17}$ Although Alexander Legge, head of the Farm Board, indicated his willingness to sell-not give- the wheat to charity organizations, nothing came of these early suggestions. ${ }^{18}$

A novel ideal for the relief use of wheat was proposed by E. N. Hopkins of the Meredith Publishing Company. He urged that wheat "be distributed to the worthy poor" through the Red Cross and Public Welfare Bureau Channels. Hopkins emphasized the necessity of feeding "starving humanity" and suggested that Hoover could not only gain credit but also "stabilize farm prices and ... stop the mouths of thousands of people who are criticizing the government. . . ." 19

Congress took up the wheat question in the winter of 193132. Again the Farm Board emphasized that it must be paid for the wheat and President Hoover was understood to oppose the measure. The Senate adopted the plan; the House at first refused, but then approved the donation of wheat to the Red Cross for distribution to the needy with no restriction on natural or economic origins. ${ }^{20}$ The president, it was understood, still opposed the measure but would sign the bill. He did not consider this a dole since the government would be distributing a commodity rather than cash. ${ }^{21}$ The Farm Board still insisted that it should be paid for the wheat. The Red Cross remained hesitant, emphasized the difficulties and dangers of the program, but pledged to do its duty. ${ }^{22}$ In the next eleven months,

${ }^{17} I$ bid.; J. R. McCleskey to Herbert Hoover, December 5, 1930, File L-E/161.

${ }^{18}$ Clipping, Chicago Evening Post, October 23, 1930, File 1-E/161, HPL. Apparently Colonel Arthur Woods, head of the Committee on Employment, did not support the idea. Isaac Sprague to Theodore Roosevelt, July 22, 1933; Joseph M. Rothschild to Herbert Hoover, July 21, 1931; J. W. Krueger to Edgar Rickard, August 7, 1931, File 1-E/161, HPL.

${ }^{19}$ E. N. Hopkins to President Hoover, July 27, 1931; Charles D. Reid to E. N. Hopkins, August 1, 1931, File 1-E/161, HPL.

${ }^{20}$ New York Times, February 25, March 2, 7, 1932.

${ }^{21}$ New York Times, January 5, March 6, 8, 1932.

${ }^{22}$ James Fieser to John Barton Payne, May 19, 1932; Unsigned and undated MEMURANDUM which discussed at length the problems, File 1-E/161, HPL; John Barton Payne to Charles L. McNary, March 8, 1932, File 1-E/161, HPL. 
the Red Cross approved for distribution over eight and one half million barrels of flour to $5,140,855$ families in all but forty-five of the 3,072 counties of the nation. In addition, over 220,000 tons of stock feed were distributed. ${ }^{23}$ The value of the wheat as a relief item was obvious.

Although Hoover and the Red Cross cooperated in the wheat distribution, they did so without eagerness. By 1932 it would have been all but impossible to refuse this most limited relief effort. Not even one unit of the Chamber of Commerce supported wheat distribution. ${ }^{24}$ Although flour and bread were the major items in Red Cross Depression relief, by mid-1932 the organization had moved into the unemployment field in a major way.

The food relief issue had grave effects on President Hoover. Will Rogers, who helped raise money for the Red Cross, warned ". . . you let this country get hungry and they are going to eat, no matter what happens to budgets, income taxes, or Wall Street values. Washington mustn't forget who rules when it comes to a showdown." Herbert Hoover forgot. Americans compared the vigorous and big-hearted relief role of Hoover in the First World War, Russian Civil War and the Mississippi Flood of 1927 with his opposition, or at best reluctant acquiesence, to food for hungry Americans during the early Depression years.

Hoover might have seized the initiative in the drought crisis and food relief issue without seriously violating his faith in "voluntary cooperation" and his determination to prevent significant expansion of the federal bureaucracy. Instead he vigorously opposed direct government food aid and made no real effort to lead a vast voluntary assistance program. Rather than lead a great humanitarian drive to help the needy, he permitted opposition politicians to charge that he would "feed Jackasses but not starving babies," to coin the terms "Hoover apples" for turnips, and "Hoover Hogs" for jackrabbits, and to describe the president as cold and hard hearted. Hoover was not hard hearted but he was severely limited either in political reality or by philosophical rigidity or both. As late as January 1932 he sug-

\footnotetext{
${ }^{23}$ Report, Red Cross Relief Activities, February 18, 1933, File 1-E/62, HPL.

${ }^{24}$ Mitchell Chamber of Commerce, Carl I. Rolston to the President, February 21, 1932, File 1-E/161, HPL.
} 


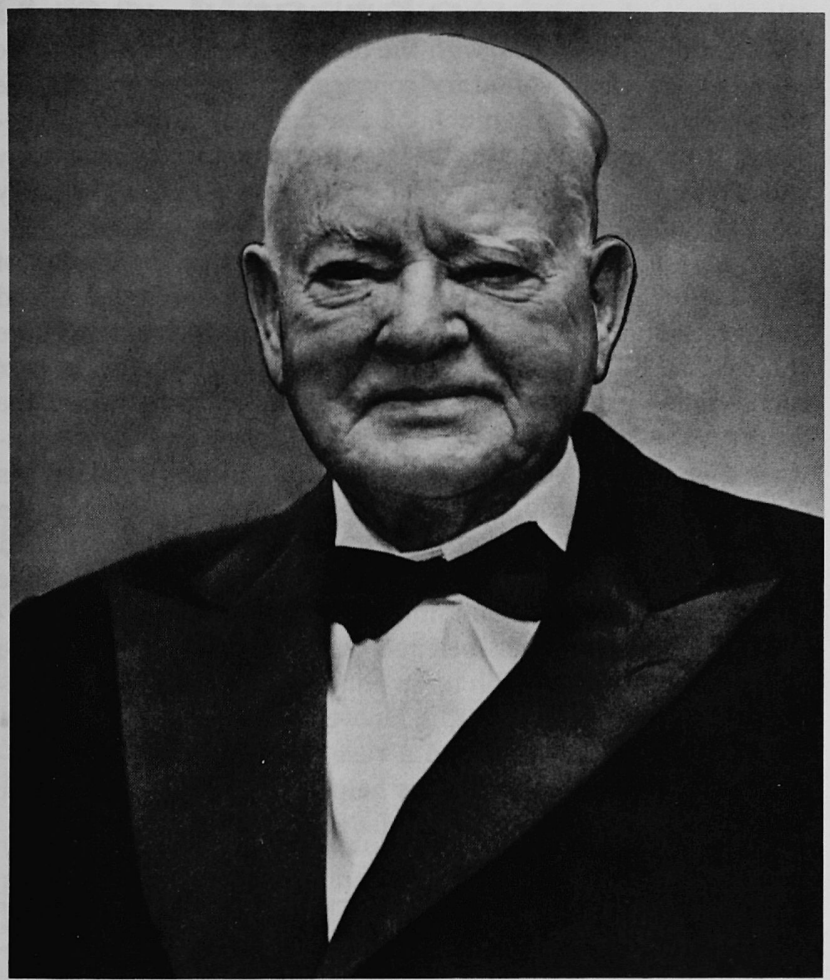

Herbert Hoover at age eighty-three.

gested that five or ten million dollars donated "by substantial men" would see the country through the relief needs of the year "without a breakdown in our fundamental ideas of government." ${ }^{25}$ While Hoover forced the Red Cross into relief and a broadened concept of its responsibilities, he continued to place his faith in an elitist concept of charity. Had the president in the fall of 1930 used the leadership abilities he demonstrated in the

${ }^{25}$ C. Roger Lambert, "Herbert Hoover and Federal Farm Board Wheat," Heritage of Kansas, 10 (1977): 29-30. 
role of food administrator during World War I and launched a nation-wide effort to deal with the drought crisis, he might have stimulated a vast "voluntary cooperation" movement and he could have fended off much of the political attack that developed. Instead, he made clear his opposition to the use of any federal funds or aid for individual relief and appeared not only reluctant but heartless as Congress forced it upon him. ${ }^{26}$

With millions of bushels of surplus wheat in the control of the Federal Farm Board, Hoover might have developed a food program giving him the impetus and political following to have changed the history of the Depression and of politics for the next twenty years. The president might have added to the wheat the concerted and organized drive for voluntary support he demonstrated in the previous relief efforts and thereby retained his reputation as the world's greatest humanitarian. Again, he opposed and gave ground grudgingly and his final reluctant and half-hearted acceptance of the wheat for relief use was public knowledge.$^{27}$ Instead of building on his reputation of aiding suffering humanity, Hoover forfeited the humanitarian role to the Democratic Party and with it the political impetus. The food relief issue helped to destroy the Hoover presidency and it paved the way for the New Deal and a vast array of federal food programs. Through inaction Hoover helped birth the thing he most feared-a vast expansion of the federal bureaucracy. ${ }^{28}$

\footnotetext{
${ }^{26}$ Clearly Hoover called upon private effort in his appeal to the Red Cross and in his call for donations to the Red Cross. This effort did not receive the best efforts of either president or the public. It may be that Hoover felt the constraints of office and was unwilling to use the propaganda efforts of the earlier period. Whether it was philosophical restraints, sense of office, an unvoiced recognition that voluntary contributions could not meet the needs, or an unrecognized lack of leadership ability is not clear. It is clear that for such a staunch advocate of voluntary solutions, Hoover made a minimum effort to get voluntary action.

${ }^{27}$ It might be argued that Hoover was simply holding to his established principles. This is kinder than to accuse him of political stupidity, hard heartedness, or even lack of awareness of the hunger problems in the country. It is equally simplistic and almost certainly inaccurate. To use federal wheat to feed Americans seems to most less a violation of tradition or "voluntary effort" than federal aid to business corporations.

${ }^{28}$ It is possible even probable that no voluntary program even with the best efforts of the president, would have made a significant difference in the Depression. Politically a more active and flexible role by Hoover might have made a great difference.
} 
Copyright of Annals of Iowa is the property of State of Iowa, by \& through the State Historical Society of Iowa and its content may not be copied or emailed to multiple sites or posted to a listserv without the copyright holder's express written permission. However, users may print, download, or email articles for individual use. 